\title{
The influence of royal jelly and human interferon-alpha (HuIFN-aN3) on proliferation, glutathione level and lipid peroxidation in human colorectal adenocarcinoma cells in vitro
}

\author{
Bratko Filipič ${ }^{1}$, Lidija Gradišnik ${ }^{4}$, Klemen Rihar ${ }^{2}$, Eugen Šoošs ${ }^{5}$ Adriana Pereyra ${ }^{3}$, and \\ Jana Potokar ${ }^{3}$ \\ Institute for Microbiology and Immunology, Medical Faculty, University of Ljubljana ${ }^{1}$, Chengdujska $4^{2}$, Medex d.o.o. ${ }^{3}$, \\ Ljubljana, Medical Faculty, University of Maribor, Maribor', Slovenia, Trg Sv. Ivana 5, Kloštar Ivanić, Croatia ${ }^{5}$
}

[Received in March 2015; CrossChecked in March 2015; Accepted in November 2015]

\begin{abstract}
Among royal jelly's (RJ) various biological activities, its possible antitumour activity deserves particular attention. The purpose of this study was to investigate the influence of RJ, its bioactive component 10-hydroxy-2-decenoic acid (10$\mathrm{HDA}$ ), and human interferon-alpha (HuIFN- $\mathrm{NN3}$ ) on the proliferation of human colorectal adenocarcinoma cells (CaCo2), and ascertain their effect on intracellular glutathione (GSH) level and lipid peroxidation. We studied the antiproliferative (AP) activity of RJ [(0.1 g/10 mL phosphate buffer saline (PBS)], HuIFN- $\alpha \mathrm{N} 3\left(1000 \mathrm{I} . \mathrm{U} \cdot \mathrm{mL}^{-1}\right), 10-\mathrm{HDA}$ at $100.0 \mu \mathrm{mol} \mathrm{L} \mathrm{L}^{-1}$, and their different combinations, in the ratio 1:1, 1:2, and 2:1 on CaCo-2 cells. The GSH level was measured by glutathione assay. The lipid peroxidation was measured by malondialdehyde (MDA) assay. Single RJ had a low AP activity: 2.0 $\left(0.5 \mathrm{mg} \mathrm{mL}^{-1}\right)$. HuIFN- $\alpha \mathrm{N} 3$ had an AP activity of 2.5 (208.33 I.U. $\left.\mathrm{mL}^{-1}\right)$, while 10-HDA had an AP activity of 1.5 $\left(37.5 \mu \mathrm{mol} \mathrm{mL} L^{-1}\right)$. The highest AP activity of 3.8 was obtained when RJ and HuIFN- $\alpha \mathrm{N} 3$ were applied at the ratio 2:1. In that combination the level of GSH was $24.9 \pm 2.4 \mathrm{nmol} \mathrm{g}^{-3}$ of proteins ( $v s .70 .2 \pm 3.2 \mathrm{nmol} \mathrm{g}^{-3}$ in the control) and the level of MDA was $72.3 \pm 3.1 \mathrm{nmol} \mathrm{g}^{-3}$ (vs. $23.6 \pm 9.1 \mathrm{nmol} \mathrm{g}^{-3}$ in the control). It is generally assumed that 10-HDA, an important constituent of RJ, together with HuIFN- $\alpha \mathrm{N} 3$, is responsible for the inhibition of CaCo-2 cells proliferation in vitro. In our study, however, RJ and HuIFN- $\alpha \mathrm{N} 3$ applied at 2:1 decreased the level of GSH the most and significantly increased lipid peroxidation via MDA in $\mathrm{CaCo}-2$ cells. Future studies should show whether these GSH- and MDA-related activities of RJ, HuIFN- $\alpha \mathrm{N} 3,10-\mathrm{HDA}$, and their combinations may decrease the tumorigenicity index and tumorigenic potential of various tumour cells in vitro.
\end{abstract}

KEY WORDS: antiproliferative activity; antitumour activity; CaCo-2 cells; 10-hydroxy-2-decenoic acid; malondialdehyde

Royal jelly (RJ) is a milky material secreted by the hypopharyngeal and mandibular glands of young worker bees between the sixth and twelfth day of their life. It is food exclusively for the queen honey bee (Apis mellifera) larva, which leads to the development of a sexually mature queen bee $(1,2)$. Chemically, RJ comprises water $(50-$ $60 \%$ ), different proteins $(18.0 \%)$, carbohydrates $(15.0 \%)$, lipids (3-6\%), mineral salts (1.5\%), and vitamins, together with a large number of bioactive substances, such as 10-hydroxy-2-decenoic (10-HDA) acid (3). RJ exhibits various immunomodulatory and antiproliferative properties, as well as possible antitumour activity. It also contains different antibacterial proteins like $350-\mathrm{kDa}$ protein stimulating the proliferation of human monocytes (4-6). In addition, the RJ Protein ${ }_{30}$ fraction exhibits a clear cytotoxic effect on HeLa cells by decreasing the initial cell population by $50 \%$ at the end of treatment (7).

Correspondence to: Dr Bratko Filipič, Institute for Microbiology and Immunology, Medical Faculty, University of Ljubljana, Zaloška 4, 1105 Ljubljana, Slovenia, E-mail: Bratko.Filipic@gmail.com
HuIFN- $\alpha$ N3, a type I interferon, is a multisubtype protein $(8,9)$ with antiviral, antiproliferative, and antitumour activity (10). It has been used clinically in the treatment of various cancers for over 30 years (11). The molecular mechanism behind its cytoreductive action is still not clear. The antiproliferative effect of HuIFN- $\alpha$ N3 plays a central role in its chemotherapeutic effect. Recent research (12) has also indicated its action in apoptosis pathways as a possible anti-tumour mechanism. It was also shown that HuIFN- $\alpha \mathrm{N} 3$ can exert a direct cytotoxic effect on different malignant cells and tumour cell lines in vitro (13).

Glutathione (GSH), a low molecular weight thiol, has a central role in the control of the cellular thiol/disulphide redox state, bearing significance for normal redox signalling in cells, among them also in the CaCo- 2 cells used in this study (14). Intracellular GSH concentration, cell proliferation, and apoptosis are mutually connected. A high level of GSH enhances cell proliferation, while GSH 
depletion results in the inhibition of $\mathrm{CaCo}-2$ cell growth and proliferation, due to the increase of apoptosis.

Lipid peroxidation, or oxidative degradation of lipids, is a process by which free radicals "steal" electrons from the lipids in cellular membranes inducing cell damage. It proceeds by a free radical chain reaction mechanism $(15$, 16). The end-products of lipid peroxidation are reactive aldehydes with carcinogenic potential. Among them, the most important is malondialdehyde (MDA), a major bioactive marker of lipid peroxidation that exerts numerous biological activities resembling activities of reactive oxygen species.

The aim of this study was to investigate the effect of RJ and 10-HDA on HuIFN- $\alpha$ N3-induced inhibition of CaCo2 cells proliferation in vitro and ascertain their effect on the intracellular level of GSH and lipid peroxidation via MDA activity. We assumed that such an approach might serve to establish possible antiproliferative/antitumor mechanisms in human colorectal adenocarcinoma cells, which could be of value for developing future anticancer treatments based on the use of these bioactive compounds.

\section{METHODS}

\section{Material}

The following materials were used: Human Interferon $-\alpha \mathrm{N} 3$, (HuIFN- $\alpha \mathrm{N} 3$ ) (Institute of Immunology, Zagreb, Croatia) applied at 1000 I.U. $\mathrm{mL}^{-1}$, which was a standard concentration previously used in experiments (17). Royal jelly-fresh (Mižigoj, Ljubljana, Slovenia) (RJ-F(M)) (MEDEX d.o.o., Ljubljana, Slovenia), was applied at 0.1 g/10 mL (18). 10-hydroxy-2-decenoic acid (10-HDA) (Sigma-Aldrich, Missouri, USA) was applied at $100 \mu \mathrm{mol} \mathrm{L}^{-1}$ (19). All of the reagents were dissolved in the phosphate buffer saline (PBS), $\mathrm{pH}=7.2$ and then filtered through a 0.2 $\mu \mathrm{m}$ syringe filter (Millipore, USA).

\section{Cell culture}

CaCo-2 cells (Institute for Microbiology and Immunology, Ljubljana, Slovenia) were cultivated in Eagle's medium with L-Glutamine $\left(2.0 \mathrm{mmol} \mathrm{L}^{-1}\right)$ (SigmaAldrich, Missouri, USA) and antibiotics: Penicillin (100 units $\left.\mathrm{mL}^{-1}\right)$, Streptomycin $\left(100 \mu \mathrm{g} \mathrm{mL} \mathrm{m}^{-1}\right)$, and Gentamycin $\left(50 \mu \mathrm{g} \mathrm{mL}^{-1}\right)$ (Sigma-Aldrich, Missouri, USA) and supplemented with $10 \%$ of foetal calf serum (FCS) (Sigma-Aldrich, Missouri, USA). Before the experiment, the cells were multiplied and their viability and capability for proliferation was assayed by the MTT Cell Proliferation Assay Kit (K299-100) (BIOVISION, Milpitas, California, USA). The cell cultivation was performed in 96-well flat microtiter plates in $5 \% \mathrm{CO}_{2}$ at $37{ }^{\circ} \mathrm{C}$ or in $25 \mathrm{~cm}^{2}$ flasks (Sterilin, Sigma-Aldrich, Missouri, USA) in $5 \% \mathrm{CO}_{2}$ at $37^{\circ} \mathrm{C}$.

\section{Design of the study}

The experiments were designed as follows: single substances: RJ-F(M), HuIFN- $\alpha$ N3 and 10-HDA in the previously stated concentrations, were added alone in a volume of $100 \mu \mathrm{L} /$ well. When different combinations between them were used, for the ratio 1:1 100+100 $\mu \mathrm{L} /$ well was added. For the ratio $1: 2,66.8+133.2 \mu \mathrm{L} /$ well and for the ratio $2: 1,133.2+66.8 \mu \mathrm{L} /$ well was added.

\section{Antiproliferative (AP) activity}

Single substances or their combinations, as described in the design of the study, were added in a volume of $200 \mu \mathrm{L}$ per well in the first well in row of 96-well flat microtiter plates, and the samples were serially transferred per $100 \mu \mathrm{L}$ from 1:2 to 1:4096 in Eagle's medium with L-Glutamine and antibiotics. After the substances, the cells ( $\mathrm{CaCo}-2)$ were added $\left(10^{4}\right.$ cells/well/100 $\left.\mu \mathrm{L}\right)$ in Eagle's medium with L-Glutamine and antibiotics and $10 \%$ FCS. The cells without substances were added separately (the negative control). As positive controls, single tested substances (RJ, HuIFN- $\alpha$ N3, 10-HAD) were used. The microtiter plates were incubated for 72 hours at $37{ }^{\circ} \mathrm{C}$ in a $5 \% \mathrm{CO}_{2}$ atmosphere. Afterward, the supernatants were discharged and the cells were fixed with the addition of $100 \mu \mathrm{L} /$ well of $10 \%$ formalin (Sigma-Aldrich, Missouri, USA) in PBS. After two hours, the fixative was removed and the cells were washed twice with the PBS. After that, $2 \%$ Rhodamine B (Sigma-Aldrich, Missouri, USA) $(100 \mu \mathrm{L} /$ well) was added for 15 minutes. This was then removed, and the cells were washed twice with PBS and air-dried. On the dried plates, the optical density (OD) at $550 \mathrm{~nm}$ was measured (Synergy HTX Multi Mode Reader with Gen 5 software, Biotek, Winooski, USA). The AP activity was determined with the well in rows where $50 \%$ cell growth inhibition was found. The $\mathrm{AP}_{50}$ was calculated for each separate substance (RJ, HuIFN $\alpha$ N3, and 10-HDA) (20).

\section{Glutathione determination}

CaCo- 2 cells were cultivated in $25 \mathrm{~cm}^{2}$ flasks (Sterilin, Sigma-Aldrich, Missouri, USA) in Eagles' medium with L-Glutamine and antibiotics and $10 \%$ FCS. When monolayers were developed, the cells in flasks were treated with substances alone or their combinations in a volume of $1.0 \mathrm{~mL}$ when single substances were added, and a total of $2.0 \mathrm{~mL}$ when the combinations were added. The cells were treated for 24 hours at $37^{\circ} \mathrm{C}$ and $5 \% \mathrm{CO}_{2}$. The medium was removed, and the cells were detached with trypsin (SigmaAldrich, Missouri, USA) and treated with $1 \mathrm{~mL}$ of $10 \mathrm{mmol} \mathrm{mL}-1$ Tris- $\mathrm{HCl}$ solution $(\mathrm{pH}=6.0)$ containing $0.5 \mathrm{~mol} \mathrm{~mL}^{-1}$ diethylene triamine pentacetic acid (DTPA) (Sigma-Aldrich, Missouri, USA), and syringed several times with an insulin syringe for their lysis. The cell protein amount was determined by Bio-Rad protein assay (Bio-Rad Laboratories, Hercules, California, USA) and Bovine serum albumin (BSA) (Sigma-Aldrich, Missouri, USA) as a 
standard. For total GSH determination, $100 \mu \mathrm{L}$ of DL-

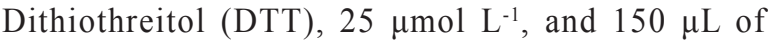
$0.1 \mathrm{~mol} \mathrm{~mL}^{-1}$ Tris- $\mathrm{HCl}(\mathrm{pH} 8.5)$ were added to $50 \mu \mathrm{L}$ of the cell lysate. After 30 minutes on ice, the proteins were precipitated by adding $750 \mu \mathrm{L}$ of $2.5 \%$ (wt./vol) 5-sulfosalicilic acid and centrifuged at $13000 \mathrm{~g}$ (Centric, Tehtnica d.o.o., Železniki, Slovenia) for 4 minutes at $4{ }^{\circ} \mathrm{C}$. The cellular supernatants were used in Glutathione Assay Kit (Sigma-Aldrich, Missouri, USA) to measure the GSH level at OD at $412 \mathrm{~nm}$ (Synergy HTX Multi Mode Reader with Gen 5 software, Biotek, Winooski, USA) and expressed as nmol of $\mathrm{GSH} \mathrm{g}^{-3}$ of proteins.

\section{Measurements of lipid peroxidation}

$\mathrm{CaCo}-2$ cells were cultivated in $25 \mathrm{~cm}^{2}$ flasks (Sterilin, Sigma-Aldrich, Missouri, USA) in Eagles' medium with L-Glutamine and antibiotics and $10 \%$ FCS. When the monolayer was formed, the cells were treated with substances alone or their combinations as described in the design of the study, in a quantity of $1.0 \mathrm{~mL}$ when single substances were added, and a total of $2.0 \mathrm{~mL}$ when the combinations were added. The treated/non-treated cells were incubated for 24 hours at $37{ }^{\circ} \mathrm{C}$ and $5 \% \mathrm{CO}_{2}$. The medium was removed and cells detached with trypsin washed and resuspended in $5 \mathrm{~mL}$ of PBS. Cell protein concentration was determined using the Bio-Rad protein assay (Bio-Rad Laboratories, Hercules, California, USA) and BSA as a standard. A measure of $1 \mathrm{~mL}$ of thiobarbituric acid (TBA) reagent $(0.38 \% 2$-TBA, $15.0 \%$ TBA, $0.3 \mathrm{~mol}$ $\mathrm{mL}^{-1} \mathrm{HCl}$ ) was added to the cell suspension. The samples were heated at $95{ }^{\circ} \mathrm{C}$ for 20 minutes, chilled to room temperature and centrifuged at $1500 \mathrm{~g}$ for 10 minutes. The
TBA reactive substances (RS) developed by lipid peroxidation were measured in the supernatant at OD at 535 nm (Synergy HTX Multi Mode Reader with Gen 5 software, Biotek, Winooski, USA), according to the TBA method $(21,22)$. The results were expressed as MDAnmol g-3 of protein.

\section{Data analysis}

T-test was used for significance determination $(* p<0.1$, $* * p<0.05)$; data are shown as mean value \pm standard deviation. Each of the tests was performed in triplicate and each experiment was repeated three to four times.

\section{RESULTS AND DISCUSSION}

\section{Antiproliferative activity}

The following results of AP activity and concentrations at $\mathrm{AP}_{50}$ for single substances were obtained: $\mathrm{RJ}: 2.0$ (0.5 mg mL $\left.{ }^{-1}\right)$, HuIFN- $\alpha \mathrm{N} 3: 2.5$ (208.33 I.U. $\left.\mathrm{mL}^{-1}\right)$ and 10-HDA: $1.5(37.5 \mu \mathrm{mol} \mathrm{L}-1)$. The observed AP activity was relatively low. The AP activity of their combinations $(1: 1,1: 2,2: 1)$ is shown on Figure 1.

The highest AP activity was obtained when the combination of RJ-F (M) and HuIFN- $\alpha$ N3 was used in a $2: 1$ ratio. In this case the AP activity was 3.8 . When the combination of the RJ-F (M) component 10-HDA and HuIFN- $\alpha$ N3 2:1 was tested, the AP activity was 2.4-2.6, which was much lower than with RJ-F (M) and HuIFN$\alpha \mathrm{N} 3$. Such results suggest that RJ-F $(\mathrm{M})$ could contain some

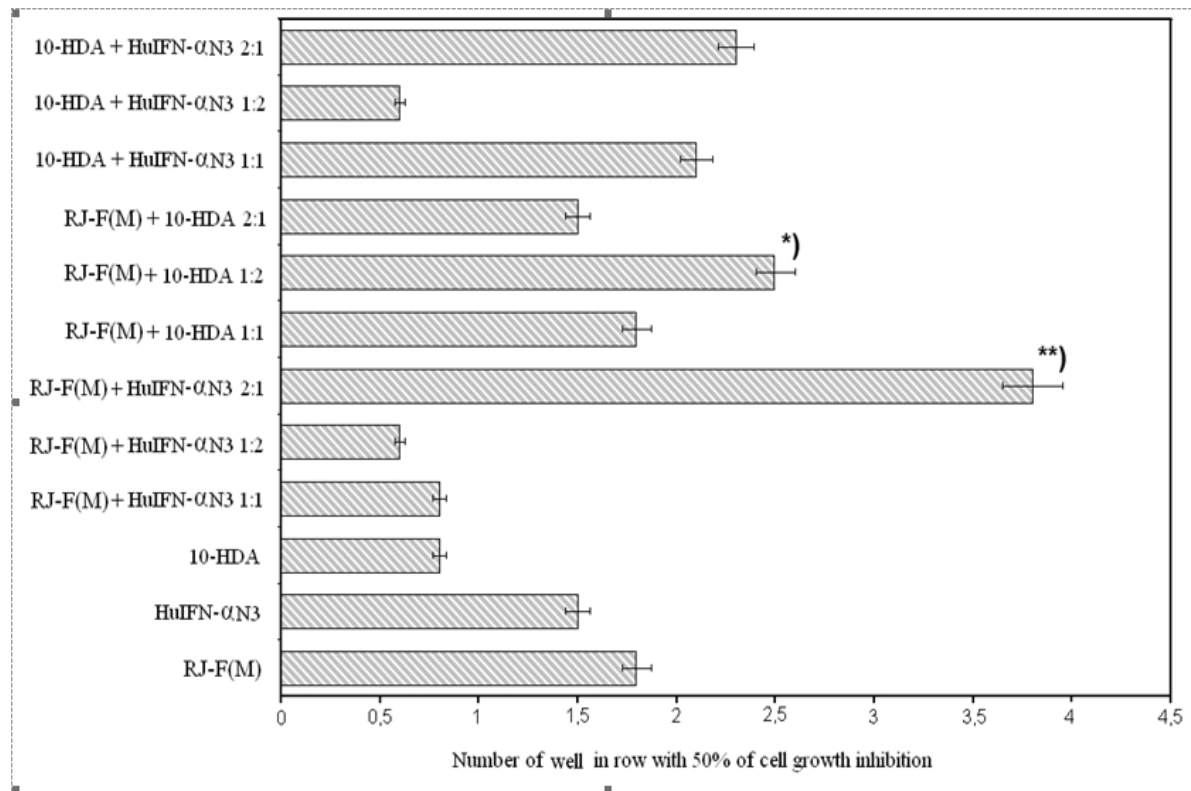

Figure 1 The AP effect of RJ-F (M), HuIFN- $\alpha N 3,10-H D A$ and their combinations (1:1, 1:2 and 2:1) on the CaCo-2 cell line. Inhibition of proliferation of CaCo-2 cell line treated with RJ-F (M) (0.1 g/10 mL PBS), HuIFN- $\alpha N 3$ (1000 I.U. mL $\left.L^{-1}\right), 10-H D A\left(100 \mu m o l ~ m L^{-1}\right)$ and different combinations between them (1:1, 1:2 and 2:1) was analysed. The AP activity was determined by Rhodamine B staining method after $72 \mathrm{~h}$ of incubation at $37^{\circ} \mathrm{C}$ and $5 \% \mathrm{CO}$. The $t$-test was used for significance determination $\left({ }^{*} \mathrm{p}<0.1, * * \mathrm{p}<0.05\right)$; data are shown as mean value \pm standard deviation 
other components responsible for the relatively strong AP activity of the combination RJ-F (M) and HuIFN- $\alpha \mathrm{N} 3$ in the ratio $2: 1$. In this respect, the possible role of the RJ Protein $_{30}$ water soluble fraction that previously exhibited the clear cytotoxic effect on HeLa cells by decreasing the initial cell population by $50 \%$ at the end of treatment (7) should be also anticipated.

It is known that the AP activity of the RJ-F (M), HuIFN$\alpha \mathrm{N} 3,10-\mathrm{HDA}$ on the CaCo-2 cells is connected with the induction of apoptosis and cytotoxicity (14). Also their influence on the glutathione level and lipid peroxidation was found (23).

\section{GSH determination and measurement of lipid peroxidation}

The results obtained in our study show that RJ-F (M), HuIFN- $\alpha$ N3, 10-HDA and their combinations decreased the level of glutathione and increased the lipid peroxidation via the MDA. Detailed data are shown in Table 1.

Glutathione (GSH) plays an important role in many cellular processes, like cell differentiation, proliferation, and apoptosis and cancer. While GSH deficiency, or a decrease in the GSH/glutathione disulphide (GSSG) ratio, leads to an increased susceptibility to oxidative stress in the progression of cancer, elevated GSH levels increase the antioxidant capacity and resistance to oxidative stress found in cancer cells. It is important to stress that RJ-F (M), HuIFN- $\alpha$ N3, 10-HDA, and their combinations decreased the level of glutathione and significantly increased the lipid peroxidation via the MDA.

Some of the mechanisms of the possible antitumour mechanisms of royal jelly are connected with the modulation of the oxidative stress and induction of apoptosis. (24). Practically the same effects were found after the treatment of the Pancreatic Cancer Cell tumour cells $\mathrm{PaCa}-44$ with 10 -HDA, where the induction of the apoptosis was found (25). It is interesting to note that the antitumour activity of HuIFN- $\alpha \mathrm{N} 3$ was also connected with the induction of apoptosis and the modulation of the oxidative stress in rats with breast cancer (26).

The most important finding of our study is that royal jelly, especially its constituent 10-HDA and HuIFN- $\alpha$ N3 had similar active points in the antitumor activity, which in proper ratio can be enhanced. It can be concluded, that the most active was combination of RJ-F(M) and HuIFN- $\alpha \mathrm{N} 3$ 2:1, where the level of the GSH was $24.9 \pm 2.4 \mathrm{nmol} \mathrm{g}^{-3}$ of proteins ( $v s .70 .2 \pm 3.2 \mathrm{nmol} \mathrm{g}^{-3}$ in the control) and the level of MDA $72.3 \pm 3.1 \mathrm{nmol} \mathrm{g}^{-3}$ (vs. $23.6 \pm 9.1 \mathrm{nmol} \mathrm{g}^{-3}$ in the control).

Future experiments will show whether these GSH- and MDA- related activities of RJ-F (M), HuIFN- $\alpha \mathrm{N} 3,10-\mathrm{HDA}$ and their combinations may cause the decrease of the tumorigenicity index of different tumour cells in vitro, as previously reported in the literature $(27,28)$, also through their tumorigenic potential. This is important for the practical use of royal jelly (10-HDA) and HuIFN- $\alpha \mathrm{N} 3$ in a combination that could be of value for future development of tumour therapy based on the use of bioactive compounds.

\section{Conflict of Interests}

All the authors declare no conflict of interest.

\section{Acknowledgement}

The research was supported by a grant from the Slovenian Research Agency: ARRS-NRU/P3-0083-03812014. Authors are indebted to Tomaž Velnar for English suggestions.

Table 1 Glutathione (GSH) determination and measurement of lipid peroxidation (MDA) after the CaCo-2 cells treatment with RJ, HuIFN- $\alpha N 3,10-H D A$ and their combinations: 1:1, 1:2 and 2:1 ${ }^{a}$

\begin{tabular}{|c|c|c|}
\hline Sample & Glutathion (GSH) ${ }^{b}$ & Malondialdehyde (MDA) \\
\hline & $($ Mean \pm SE) & $(\mathrm{Mean} \pm \mathrm{SE})$ \\
\hline Cell control & $70.2 \pm 3.2$ & $23.6 \pm 9.1$ \\
\hline $\mathrm{RJ}-\mathrm{F}(\mathrm{M})^{\mathrm{d}}$ & $43.8 \pm 2.8$ & $30.2 \pm 4.3$ \\
\hline HuIFN- $\alpha$ N3 & $28.7 \pm 6.4$ & $38.6 \pm 4.2$ \\
\hline $10-\mathrm{HDA}^{\mathrm{e}}$ & $33.6 \pm 5.8$ & $50.7 \pm 4.6$ \\
\hline RJ-F(M)+HuIFN- $\alpha$ N3 1:1 & $45.2 \pm 4.7$ & $43.6 \pm 4.1$ \\
\hline RJ-F(M)+HuIFN- $\alpha$ N3 1:2 & $40.8 \pm 3.1$ & $58.3 \pm 5.2$ \\
\hline RJ-F(M)+HuIFN- $\alpha$ N3 2:1 & $24.9 \pm 2.4 * *$ & $72.3 \pm 3.1 * *$ \\
\hline RJ-F(M)+10-HDA 1:1 & $40.6 \pm 4.5$ & $43.1 \pm 2.6$ \\
\hline RJ-F(M)+10-HDA 1:2 & $37.2 \pm 2.1$ & $50.6 \pm 4.5$ \\
\hline RJ-F(M)+10-HDA 2:1 & $30.3 \pm 3.7^{*}$ & $61.6 \pm 5.2 *$ \\
\hline 10-HDA+HuIFN- $\alpha$ N3 1:1 & $29.5 \pm 1.7$ & $49.6 \pm 4.2$ \\
\hline 10-HDA+HuIFN- $\alpha$ N3 1:2 & $42.6 \pm 5.3$ & $57.2 \pm 2.6$ \\
\hline 10-HDA+HuIFN- $\alpha$ N3 2:1 & $25.6 \pm 3.1$ & $55.6 \pm 6.2$ \\
\hline
\end{tabular}




\section{REFERENCES}

1. Ramadan FM,Al-Ghamdi. Bioactive compounds and healthpromoting properties of royal jelly: a review. J Funct Foods 2012;4:39-52. doi: 10.1016/j.jff.29.11.12.007

2. Pavel IC, Margharitas AL, Bobis O, Dezmirean DS, Sapcaliu A, Radoi I, Madas NM. Biological activities of royal jelly - review. Anim Sci Biotechnol 2011;44:108-18.

3. Tahashi K, Hiroshi M. Royal jelly acid 10-hydroxy-trans-2decenoic acid as a modulator of the innate immune responses. Endocr Metab Immune Disord Drug Targets 2012;12:368-76. doi: $10.2174 / 187153012803832530$

4. Townsend GF, Morgan JF, Tolnai S, Hazlett B, Morton HJ, Shuel RW. Studies on the in vitro antitumor activity of atty acids. I. 10-Hdroxy-2-decenoic acid from royal jelly. Cancer Res 1960;20:503-10. PMID: 13839101

5. Tamura T, Fuji A, Kuboyama N. [Antitumor effects of royal jelly (RJ), in Japanese]. Folia Pharmacol Japon 1987;89:7380. doi: $10.1254 /$ fpj. 89.73

6. Watanabe K, Shinmoto H, Kobori M, Tsushida T, Shinohara $\mathrm{K}$, Kanaeda J, Yonekura M. Stimulation of cell growth in the U937 human myeloid cell line by honey royal jelly protein. Cytotechnology 1998;26:23-7. doi: 10.1023/A:1007928498128

7. Salazar-Olivio LA, Paz-González V. Screening of biological activities present in honeybee (Apis mellifera) royal jelly. Toxicology in Vitro 2005;19:645-51. doi: 10.1016/j. tiv.2005.03.001

8. Mocellin S, Lens MB, Pasquali S, Pilati P, Chiarion Sileni V. Interferon alpha for the adjuvant treatment of cutaneous melanoma. Cochrane Database Syst Rev 2013;6:CD008955. doi: 10.1002/14651858.CD008955

9. Kalliolias DG, Ivashkiv BL. Overview of the biology of type I interferons. Arthritis Res Ther 2010;12(Suppl 1):S1-9. doi: 10.1186/ar2881

10. Liu X, Lu J, He ML, Li Z, Zhang B, Zhou LH, Li Q, Li G, Wang L, Tian WD, Peng Y, Li XP. Antitumor effect of interferon alpha on cell growth and metastasis in human nasopharyngeal carcinoma. Curr Cancer Durg Targets 2013;12:561-70. doi: 10.2174/156800912800673293

11. Jonasch E, Hluska GF. Interferon in oncological practice: review of interferon biology, clinical application and toxicities. Oncologist 2001;6:34-55. doi: 10.1634/ theoncologist.6-1-34

12. Jedema I, Barge RMY, Willemze R, Falkenburg JH. High suspectibility of human leukemic cells to Fas-induced apoptosis is restricted to G1 phase of the cell cycle and can be increased by interferon treatment. Leukemia 2003;17:57684. doi: 10.1038/sj.leu.2402844

13. Peek SF, Bonds MD, Gangemi DG, Thomas CB, Schultz RD. Evaluation of cytotoxicity and antiviral activity of recombinant human interferon alfa- $2 \mathrm{a}$ and recombinant human interferon alfa-B/D hybrid against bovine viral diarrhea virus, infectious bovine rhinotracheitis virus, and vesicular stomatitis virus in vitro. Am J Vet Res 2004;65:8714. doi: 10.2460 /avjr.2004.65.871

14. Ziegler TR, Nkabyo SY, Gu LH, Watson WH, Jones DP. Glutathione and theredoxin during the differentiation in human colon epithelial ( $\mathrm{CaCo}-2)$ cells. Am J Physiol Gastrointest Liver Physiol 2002;283:G1352-59. doi: 10.1152/ajpgi.00183.2002
15. Gago-Dominguez M, Jiang X, Castelao EJ. Lipid peroxidation, oxidative stress genes and dietary factors in breast cancer protection: a hypothesis. Breast Cancer Res 2007;9:201-11. doi: 10.1186/bcr1628

16. Niki E, Yosida Y, Saito Y, Noguchi N. Lipid peroxidation: mechanism, inhibition and biological effects. Biochem Biophys Res Commun 2005;338:668-76. doi: 10.1016/j. bbrc.2005.08.072

17. Fidler JI, Heicappel R, Saiki I, Grutter GM, Horisberger AM, Nuesch J. Direct antiproliferative effects of recombinant human interferon $-\alpha \mathrm{B} / \mathrm{D}$ hybrids on human tumor cell lines. Cancer Res 1987;47:2020-7. PMID: 3828990

18. Yanagita M, Kojima Y, Mori K, Yamada S, Murakami S. Osteoinductive effect of royal jelly on periodontal ligament cells. Biomed Res 2011;32:285-91. doi: 10.220/ biomedres. 32.285

19. Mihajlović D, Vučević D, Chinou J, Čolić M. Royal jelly fatty acid modulate proliferation and cytokine production by human peripheral blood mononuclear cells. Eur Food Res Technol 2014;238:881-7. doi: 10.1007/s00217-014-2154-7

20. Borden EC, Hogan TF, Voekel JG. Comparative antiproliferative activity in vitro of natural interferons $\alpha$ and $\beta$ for diploid and transformed human cells. Cancer Res 1982;42:4948-53. PMID: 7139598

21. Buege JA, August SD. Microsomal lipid peroxidation. Methods Enzymol 1978;52:302-10. doi: 10.1016/S00766879(78)52032-6

22. Devasagayam TPA, Bloor KK, Ramasarma T. Methods for estimating the lipid peroxidation: an analysis of merits and demerits. Indian J Biochem Biophys 2003;40:300-8. PMID: 22900323

23. Traverso N, Ricciarelli R, Nitti M, Marengo B, Furfaro AL, Pronzato A, Marinari UM, Domenicotti C. Role of gluthatione in cancer progression and chemoresistence. Oxid Med Cell Longev Volume 2013; Article ID 972913: doi: $10.1155 / 2013 / 972913$

24. Karadeniz A, Simsek N, Karakus E, Yildirim S, Kara A, Can I, Kisa F, Emre H, Turkeli M. Royal jelly modulates oxidative stress and apoptosis in liver and kidneys of rats treated with cisplatin. Oxid Med Cell Longev 2011; Article ID 981793 , doi: $10.1155 / 2011 / 981793$

25. Merendino N, Loppi B, D’Aquino M, Molinari R, Pessino G, Romano C, Velotti F. Docohexaenoic acid induces apoptosis in the human $\mathrm{PaCa}-44$ pancreatic cancer cell line by active reduced glutathione extrusion and lipid peroxidation. Nutr Cancer 2005;52:225-33. doi: 10.1207/ s15327914nc5202 12

26. Eghdami A, Sohi HMS. Investigation of $\alpha$-IFN-SWNT and $\alpha$-IFN-PLGA effects on breast cancer in rats induced by DMBA by using CAIS-3 tumor marker. Adv Biores 2014;5:913.

27. Swierenga HHS, Whitfield FJ, Karasakti S. Loss of proliferative calcium dependence: simple in vitro indicator of tumorigenicity. Proc Natl Acad Sci USA 1978;75:6069-72. doi: 10.1073/pnas.75.12.6069

28. Thepot A, Desanlis A, Venet E, Thivillier L, Justin V, Morel AP, DeFraipont, Till M, Krutovskikh V, Tommasino M, Damour O, Hainaut P. Assesment of transformed properties in vitro and of tumorigenicity in vivo in primary keratinocytes cultured for epidermal sheet transplantation. J Skin Cancer Volume 2011, Article ID 936546, doi: 10.1155/2011/936546 


\section{Vpliv matičnega mlečka in humanega interferona-alfa (HuIFN- $\alpha$ N3) na proliferacijo, nivo glutationa in na preoksidacijo lipidov $v$ humanih kolorektalnih adenokarcinomskih celicah in vitro}

Kot del biološke aktivnosti MM (Matičnega mlečka) so avtorji preučevali njegovo protitumorsko delovanje kot tudi možno interakcijo s humanim interferonom alfa (HuIFN- $\alpha$ N3). Cilj opravljenih poskusov je bil preučiti vpliv kombinacije med MM in HuIFN- $\alpha \mathrm{N} 3$ na proliferacijo celic Humanega kolorektalnega adenokarcinoma (CaCo-2) in njun vpliv na znotrajcelični nivo glutationa (GSH) in peroksidacijo lipidov. Avtorji so preučevali AP (Antiproliferativno) delovanje MM (0.1 g/10 mL fosfatnega pufra) (PBS), HuIFN- $\alpha$ N3, (1000 I.U. mL $\left.{ }^{-1}\right)$, 10-hidroxy-2-decenoične kisline (10-HDA) $\left(100.0 \mu \mathrm{mol} \mathrm{L}^{-1}\right)$ in različne kombinacije med njimi $(1: 1,1: 2$ in 2:1) na celice CaCo-2 in vitro. Njihov vpliv na znotrajcelični nivo GSH so merili s pomočjo komercialnega kita. Peroksidacijo lipidov so merili s pomočjo meritve vrednosti malondialdehida (MDA). MM sam kaže AP aktivnost $2.0\left(0.5 \mathrm{mg} \mathrm{mL}^{-1}\right)$. HuIFN- $\alpha \mathrm{N} 3$ ima AP aktivnost 2.5 (208.33I.U.mL $\left.{ }^{-1}\right)$ medtem ko ima 10-HDA AP aktivnost $1.5\left(37.5 \mu \mathrm{mol} \mathrm{mL}^{-1}\right)$. AP aktivnost kombinacije MM:HuIFN- $\alpha \mathrm{N} 3(2: 1)$ je bila 3.8. Pri tej kombinaciji je bil viden vpliv na nivo GSH: $24.9 \pm 2.4 \mathrm{nmol} \mathrm{g}$ proteinov $\left(70.2 \pm 3.2 \mathrm{nmol} \mathrm{g}^{-3}\right.$ pri kontroli). Nivo MDA je bil 72.3 $\pm 3.1 \mathrm{nmol} \mathrm{g}^{-3}$ pri kontroli). 10-HDA je glavna sestavina MM, ki v kombinaciji s HuIFN- $\alpha \mathrm{N} 3$ deluje antiproliferativno na $\mathrm{CaCo}-2$ celice. MM in HuIFN- $\alpha \mathrm{N} 3 \mathrm{v}$ kombinaciji 2:1 pospešujeta peroksidacijo lipidov (MDA) in zmanjšujeta nivo glutationa (GSH). Nadaljni poskusi bodo pokazali ali z GSH- in MDA- povezane aktivnosti MM, HuIFN- $\alpha$ N3, 10-HDA in kombinacij med njimi, zmanjšujejo indeks tumorigenosti in s tem tumorigeni potencijal različnih tumorskih celic in vitro.

KLJUČNE BESEDE: antiproliferativno delovanje; CaCo-2 celice; protitumorsko delovanje; 10-hidroksi-2decenoična kislina; malondialdehidi 